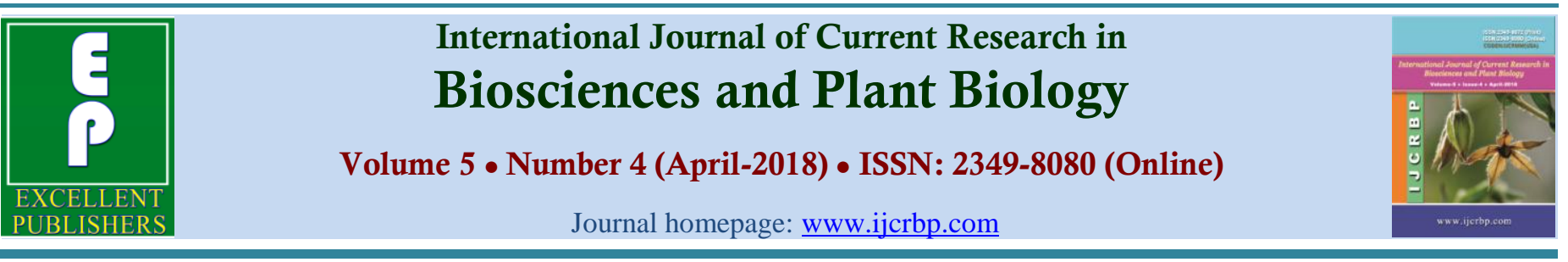

Original Research Article

doi: $\underline{\text { https://doi.org/10.20546/ijcrbp.2018.504.006 }}$

\title{
Growth and Physiological Mechanism of Phoebe chekiangensis Seedlings in Response to Lead Stress
}

\author{
Yu-Jie Yang, Wen-Jie Li and Yong-Jun Fei* \\ College of Horticulture and Gardening, Yangtze University, Hubei, 434025, China
}

${ }^{*}$ Corresponding author.

\begin{tabular}{|c|c|}
\hline Article Info & ABSTRACT \\
\hline $\begin{array}{l}\text { Date of Acceptance: } \\
21 \text { March } 2018\end{array}$ & \multirow{4}{*}{$\begin{array}{l}\text { Experiments were conducted on 1-year Phoebe chekiangensis seedlings treated by } \\
\text { different concentration }(0,300,600,900,1200 \mathrm{mg} / \mathrm{L}) \text { of } \mathrm{Pb}\left(\mathrm{NO}_{3}\right)_{2} \text {. Sixty days later } \\
\text { determination was implemented on seedling growth, physiological and photosynthetic } \\
\text { parameters. The results showed that the lower concentration treated could promote the } \\
\text { growth of the seedlings. But with the increase of concentration of lead, } P \text {. chekiangensis } \\
\text { seedling height increment, ground diameter growth, whole biomass, total root surface } \\
\text { area, root volume, total root length and root activity decreased, while root-shoot ratio } \\
\text { present a rising trend. With the increase of concentration of Pb }\left(\mathrm{NO}_{3}\right)_{2} \text { solution, the } \\
\text { membrane permeability and MDA content of } P \text {. chekiangensis seedlings showed a trend } \\
\text { of rise after the first reduce; the protein content and chlorophyll content presented a } \\
\text { trend of decrease after the first increase; while the POD, SOD and CAT activity } \\
\text { increased firstly but decreased afterwards; the net photosynthetic rate, stomatal } \\
\text { conductance, intercellular } \mathrm{CO}_{2} \text { concentration, transpiration rate were all increase at first } \\
\text { then decrease, which indicated that protection enzyme activity and membrane was } \\
\text { damaged thus the growth of } P \text {. chekiangensis seedlings was inhibited. }\end{array}$} \\
\hline $\begin{array}{l}\text { Date of Publication: } \\
\text { 06 April } 2018\end{array}$ & \\
\hline Keywords & \\
\hline $\begin{array}{l}\text { Growth } \\
\text { Lead stress } \\
\text { Phoebe chekiangensis } \\
\text { Photosynthesis } \\
\text { Physiological parameters }\end{array}$ & \\
\hline
\end{tabular}

\section{Introduction}

Heavy metal pollution becomes a serious problem in the world which could be due to the anthropogenetic activities such as industrial waste, fertilizers, sewage sludge application, dust from smelters and bad watering practices in the agriculture lands. However, heavy metals are not degraded by any process in ecosystems, only transfer by plants from abiotic to biotic system (Sharmaa et al., 2007; Mukesh et al., 2008) and threat to plants and animals and ultimately on the health of human beings via the food chain. Lead is one of the most common heavy metals contaminants in the environment. Phytoremediation has been generally considered as a cost-effective and environmental friendly method for cleaning heavy metal polluted soils (French et al., 2006). The mechanisms and application of phytoremediation has been studied in recent years (Seregin and Kozhevnikova 2008; Yan and Tam 2011; Arya et al., 2013; Lamhamdi et al., 2013; 
Kasim et al., 2014; Wińska-Krysiak et al., 2015; Zhou et al., 2017).

With the accumulation of $\mathrm{Pb}$ in the soil, lead could be taken up and enrichment in plants because $\mathrm{Pb}$ is a nonessential element for plants. When $\mathrm{Pb}$ has been absorbed by plants, $\mathrm{Pb}$ can disturb the acquisition and transport of mineral nutrition, inhibit the photosynthetic processes, accelerate free radicals and reactive oxygen species (ROS) production then causing oxidative stress in plants, reduce the enzyme activities and damage the membrane permeability, thereby impedes plants growth and development (Sharma and Dubey, 2005). The initial response of plants is the excessive generation of free radicals and ROS in plant tissues upon exposure to high levels of lead, like many other heavy metals. These ROS can lead to irreversible oxidization of lipids, proteins, chloroplastic pigments, nucleic acids, and thus affect cell viability (Foyer et al., 1994; Malecka et al., 2001; Verma and Dubey, 2003). Plants trigger both enzymatic and non-enzymatic antioxidative systems to detoxify the cells (Dalton, 1995). The antioxidant enzymes, such as superoxide dismutases (SOD), catalase (CAT), peroxidases (POD), can reduce the cellular oxidative damage an, $\mathrm{d}$ increase resistance to heavy metals (Michalak, 2006).

Phoebe chekiangensis C. B. Shang belongs to Lauraceae family, which was discovered by Chinese plant taxonomists Xiang Qibai in Zhejiang province (Xiang, 1974). It has been listed as rare and endangered species in china. $P$. chekiangensis is not only the good timber for premium furniture, carving, and precision mould, but also a potential ornamental plant in gardens and landscapes for its evergreen, tall shape, majestic crown, fast-growing and resisting wind. The previous studies were mainly focused on the growth affected by cultivation (Li and Xiang, 2004; Li and Xiang, 2006; Wang et al., 2013ab; Li et al., 2015; Qiu et al., 2016), population structure (Zang et al., 2015) and tissue culture (Huang, 2017). However, it was a blank on the heavy metal stress in $P$. chekiangensis. Lead is one of the ubiquitously distributed most abundant toxic elements in the soil (Yadav, 2010). Therefore, it is necessity to study on the response of $P$. chekiangensis under the $\mathrm{Pb}$ stress and screen out more potential plants for phytoremediation.

The purposes of this study were aimed to understand the effects of $\mathrm{Pb}$ stress on growth, physiological characteristics and photosynthetic parameters in $P$. chekiangensis seedlings, and explore the possible mechanisms in the $\mathrm{Pb}$ stress. The results will provide information and scientific guidance on cultivation and landscape application of $P$. chekiangensis.

\section{Materials and Methods}

\section{Experimental materials and preparation method}

Phoebe chekiangensis seeds were collected from Phoebe chekiangensis test site in Jingmen, Hubei province in November 2014. Seeds were depositing for one month after taking out the seed coat. Sown seeds into the sowing media (3:1:1 loam: sand: sawdust, $v / v / v)$ in March 2015. After germination, the 1-year healthy and uniform seedlings were transferred into plastic pots $(8 \mathrm{~cm}$ deep, $8 \mathrm{~cm}$ in diameter) in a greenhouse with a light period from natural light and temperatures of $28 / 25^{\circ} \mathrm{C}$ (day/light). The experiment was conducted $\mathrm{Pb}$ stress processing after $30 \mathrm{~d}$.

A randomized complete block design was employed in the experiment. Five different $\mathrm{Pb}$ concentrations $(0,300,600,900,1200 \mathrm{mg} / \mathrm{L})$ from $\mathrm{Pb}$ nitrate were poured into the soil for once every week lasting for $60 \mathrm{~d}$. The volume was $150 \mathrm{~mL}$ per pot every time. A total of 20 seedlings (5 per replicate) were used for each treatment. After last irrigation of $\mathrm{Pb}$ nitrate, cultured for $7 \mathrm{~d}$ and then measured each growth and physiological index.

\section{Growth and enzyme}

Seedling height and ground diameter were measured at before and $7 \mathrm{~d}$ after $\mathrm{Pb}$ treatment. The seedling height increment (SHI) and ground diameter increment (GDI) were reflected by the 
difference values between the first and second measurements.

Three seedlings were chosen randomly for each treatment, then carefully washed deionized water after rinsing with tap water, dried at $80^{\circ} \mathrm{C}$ for $48 \mathrm{~h}$ and kept at $60^{\circ} \mathrm{C}$ in an oven until completely dried for biomass weigh (shoot and root).

Fresh roots were harvested for determination of root activity and root growth indicators: root surface area, the root volume, the total number of root tip and the total root length using the following procedures.

Root activity was measured by triphenyltetrazolium chloride (TTC). Took $0.25 \mathrm{~mL} 0.4 \%$ TTC solution into $10 \mathrm{~mL}$-volumetric flask, added a small amount of $\mathrm{Na}_{2} \mathrm{~S}_{2} \mathrm{O}_{4}$ and diluted with ethyl acetate to volume, mixed sufficiently to produce red TTF.

Transferred $0.25,0.50,1.00,1.50$ and $2.00 \mathrm{~mL}$ TTF solution to $510 \mathrm{~mL}$-volumetric flask separately, added ethyl acetate to volume and mixed to get $25,50,100,150,200 \mu \mathrm{g}$ TTF standard colorimetric series, with a blank as the reference, to determine OD of the solution in the spectrophotometer $485 \mathrm{~nm}$, then with TTC concentration as the abscissa, OD as ordinate, drew standard curve.

Immersed $0.5 \mathrm{~g}$ plant root samples in $10 \mathrm{~mL}$ beaker with the mixed liquid of $0.4 \%$ TTC and $66 \mathrm{mmol} / \mathrm{L}$ phosphate buffer solution $(\mathrm{pH}=7.0)$, kept at $37^{\circ} \mathrm{C}$ for $1 \mathrm{~h}$, then added $1 \mathrm{~mol} / \mathrm{L}$ of sulfuric acid $2 \mathrm{~mL}$ to terminate reaction. Removed the root, carefully wiped it and grinded with $3-4 \mathrm{~mL}$ ethyl acetate and a small amount of quartz sand in a mortar to extract TTF, used a small amount of ethyl acetate to wash the residue for 2-3 times, then poured into the test tube, finally added ethyl acetate to $10 \mathrm{~mL}$, used a spectrophotometer for $485 \mathrm{~nm}$ colorimetry, taking the blank test (with sulfuric acid, then added the root samples) as reference, readout the OD. According to the standard curve, the reducing amount of TTC, we can get the reducing strength of TTC.
Reducing Strength of TTC= Reduction Amount of TTC $(\mu \mathrm{g}) /[$ Weight of Root Sample $(\mathrm{g}) \times$ Time $(\mathrm{h})]$

Chosen 3 root samples from each treatment for root growth indicators measurement by Epson expression 10000xl 1.0 root system scanner and analysis by WinRHIZO Pro 2005 b.

Fresh leaves were harvested for further measurement of membrane permeability, Chlorophyll content, soluble protein, MDA, POD, SOD and CAT using the following procedures.

Membrane permeability determination was according to Niu's method. Took $1.5 \mathrm{~g}$ tested plant leaf treated by different concentration, washed it carefully by distilled water and cut it as square, put into a $100 \mathrm{~mL}$ triangle flask, added $40 \mathrm{~mL}$ distilled water, shook and kept the leaves were all immersed in distilled water for $24 \mathrm{~h}$ at room temperature on a shaker, measured the electrical conductance value E1. Then put into boiling water for $30 \mathrm{~min}$, kept $24 \mathrm{~h}$ at room temperature and measured the electric conductivity E2. Used E1/E2 $\times 100 \%$ to express the relative membrane permeability $(\%)$.

The determination procedure of chlorophyll content as following: $0.2 \mathrm{~g}$ of fresh leaf blades were cut into small pieces and placed into $10 \mathrm{~mL}$ centrifuge tube with plug, filled with $95 \%$ ethyl alcohol to scale, kept in darkness for $72 \mathrm{~h}$, until the leaf pieces were completely white.

The liquid supernatant was measured the chlorophyll content. The chlorophyll in the solution was determined with a spectrophotometer at 665 and $649 \mathrm{~nm}$. Chlorophyll content was calculated according to the following formulae:

$$
\begin{gathered}
\mathrm{C}_{\mathrm{a}}=13.95 \mathrm{~A}_{665}-6.88 \mathrm{~A}_{649} \\
\mathrm{C}_{\mathrm{b}}=24.96 \mathrm{~A}_{649}-7.32 \mathrm{~A}_{665} \\
\mathrm{C}_{\mathrm{a}+\mathrm{b}}=\left(\mathrm{C}_{\mathrm{a}}+\mathrm{C}_{\mathrm{b}}\right) \times \mathrm{V} \times \mathrm{N} / \mathrm{W} / 1000
\end{gathered}
$$

Where $\mathrm{C}_{\mathrm{a}}$ is the chlorophyll $a$ content, $\mathrm{C}_{\mathrm{b}}$ is the chlorophyll $b$ content, $\mathrm{C}_{\mathrm{a}+\mathrm{b}}$ is the total chlorophyll content, and $\mathrm{A}$ is the absorbance at the specified wavelength. 
To prepare enzyme extraction, about $0.2 \mathrm{~g}$ of leaf samples were homogenized with $1.6 \mathrm{~mL}$ of $150 \mathrm{mM}$ buffer solution (containing 0.7 of $\mathrm{NaH}_{2} \mathrm{PO}_{4} \cdot 2 \mathrm{H}_{2} \mathrm{O}$ and $\left.1.64 \% \mathrm{Na}_{2} \mathrm{HPO}_{4} \cdot 12 \mathrm{H}_{2} \mathrm{O}, \mathrm{pH} 7.8\right)$ subjected to grinding with an ice-cooled mortar and pestle and finally centrifuged at $12000 \mathrm{rpm}$ for $20 \mathrm{~min}$ at $4^{\circ} \mathrm{C}$. The supernatant was collected for the determination of antioxidative enzyme activities, as well as the content of soluble protein and MDA. SOD activity was assayed following the procedure described by Dhindsa et al., (1981). CAT and POD activity was determined according to Chance and Maehly (1955). The MDA content was established by the method of Heath and Packer (1968). The soluble protein content was estimated as described by Bradford (1976).

\section{Determination of photosynthetic parameters}

A Li-6400 portable photosynthesis meter (Li-Cor Inc. USA) was used to measure the following parameters for Phoebe chekiangensis seedlings from each treatment: photosynthetic rate (Pn), transpiration rate $(\mathrm{Tr})$, stomatal conductance (Gs), and mesophyll intercellular $\mathrm{CO}_{2}(\mathrm{Ci})$. The built-in light source and $\mathrm{CO}_{2}$-suppling system were utilized to provide light energy and $\mathrm{CO}_{2}$ fixed in photosynthesis.

Photosynthetic active radiation was set at $1200 \mu \mathrm{mol} \cdot \mathrm{m}^{2} \cdot \mathrm{s}^{-1}$. In addition, $450 \mu \mathrm{mol} \cdot \mathrm{mol}^{-1} \mathrm{CO}_{2}$ was set as the external $\mathrm{CO}_{2}$ level, at which the photosynthesis measurements were made, according to the seedling-growing conditions. During the experiment, intact mature function leaf blades were chosen from the upper part of the shoots. Data from 8 replicates were used to determine all parameters.

\section{Statistical analysis}

Data were analyzed by one-way ANOVAs with the Duncan's multiple range tests to separate means, using the program SAS 10.0 (SAS Institute, Inc., Cary, NC). The correlation analysis was conducted using SPSS 18.0. Different letters in graph or tables indicate significant differences at $p<0.05$.

\section{Results and Discussion}

\section{Growth of Phoebe chekiangensis seedlings under different $\mathbf{P b}$ concentrations}

After the $\mathrm{Pb}$ stress treated, the seedling height increment, ground diameter increment, biomass and root-shoot ratio of Phoebe chekiangensis seedlings were significant influenced by the $\mathrm{Pb}$ stress (Table 1). The seedling height increment, ground diameter increment and biomass increased firstly and then decreases as $\mathrm{Pb}$ concentration increased while rootshoot ratio showed a converse trend.

At a concentration of $300 \mathrm{mg} / \mathrm{L}$, SHI, GDI and biomass reached their highest values, which were $33.33,21.67$, and $10.10 \%$ higher than the treatment without $\mathrm{Pb}$ stress (the control), respectively. At $600 \mathrm{mg} / \mathrm{L}$ of $\mathrm{Pb}, \mathrm{SHI}$ and GDI were also significant higher than the control, were 13.69 and $10.00 \%$, respectively. Under $\mathrm{T} 3$ and $\mathrm{T} 4$ treatments, the decreases were showed on the SHI, GDI and biomass, which were $20.23,16.67,18.68 \%$ and $27.98,26.67,27.02 \%$ lower than the control, respectively. There were no significant affected on the root-shoot ratio compared with the control. The root-shoot ratios under all treatments expect $300 \mathrm{mg} / \mathrm{L}$ of $\mathrm{Pb}$ were higher than the control.

\section{Root growth of Phoebe chekiangensis seedlings under different $\mathrm{Pb}$ concentrations}

As the increasing of $\mathrm{Pb}$ concentration, the total root tips, root surface area, root volume, total root length and root activity of Phoebe chekiangensis seedlings were climbed up and then declined (Table 2). At $\mathrm{Pb}$ concentration of $300 \mathrm{mg} / \mathrm{L}$, all of the indicators reached their highest values, which were 67.49, 13.47, 41.72, 19.61, and 15.24\% higher than the control, respectively. Among them, the $\mathrm{Pb}$ stress had a significantly increased on the total root tips, total root length and root activity. Under $600 \mathrm{mg} / \mathrm{L}$ of $\mathrm{Pb}$, root activity was significantly higher than the control, while the other indicators were lower than the control. Compared with $\mathrm{CK}, \mathrm{Pb}$ was significantly deceased total root length and root activity. 


\section{Physiological characteristics of Phoebe chekiangensis seedlings under different $\mathbf{P b}$ concentrations}

As the $\mathrm{Pb}$ concentration increased, the changes of physiological characteristics of Phoebe chekiangensis seedlings were shown in Fig. 1. The membrane permeability and MDA content decreased firstly then increased with an increase in $\mathrm{Pb}$ concentration. In addition, the differences among different treatments were significant except that of MDA content between the control and $600 \mathrm{mg} / \mathrm{L}$. The lowest values of membrane permeability and MDA content were $64 \%$ and $0.016 \mu \mathrm{mol} \cdot \mathrm{g}^{-1} \cdot \mathrm{FW}$ under $300 \mathrm{mg} / \mathrm{L}$ concentration treated, which were $5.88 \%$ and $26.39 \%$ significantly lower than that in the control. As well as the membrane permeability was $1.47 \%$ significantly lower than the control at a concentration of $600 \mathrm{mg} / \mathrm{L}$. At $900 \mathrm{mg} / \mathrm{L}$ and $1200 \mathrm{mg} / \mathrm{L}$ of $\mathrm{Pb}$ concentration, the membrane permeability and MDA content were significantly higher than that of the control by $2.94 \%, 4.41 \%$ and $21.24 \%, 46.65 \%$, respectively.

The soluble protein and Chlorophyll content in the treated plants leaves were shown as an increased firstly then decreased trend. At the $\mathrm{Pb}$ concentration from 300 to $900 \mathrm{mg} / \mathrm{L}$, the soluble protein and chlorophyll content were higher than that in the control. The highest values were reached at $600 \mathrm{mg} / \mathrm{L} \mathrm{Pb}$, and were 1.4184 and $3.1694 \mathrm{mg} / \mathrm{g}$ which were 87.50 and $41.12 \%$ higher than that of the control, respectively. Beside for the soluble protein content at $600 \mathrm{mg} / \mathrm{L}$ concentration, all treatments had no significant difference of control. But at 300 and $600 \mathrm{mg} / \mathrm{L}$ concentration, the soluble protein and chlorophyll content were significantly higher than that at $1200 \mathrm{mg} / \mathrm{L}$.

The effect of different $\mathrm{Pb}$ concentration on the antioxidant enzyme activities of Phoebe chekiangensis seedlings was shown in Fig. 1. As an increase of $\mathrm{Pb}$ concentration, all of the antioxidant enzyme activities were increased firstly then decreased. At $300 \mathrm{mg} / \mathrm{L}$ and $600 \mathrm{mg} / \mathrm{L}$ concentration, the SOD, CAT, and POD activities were higher than that of the control. And the highest values were $332 \mathrm{U} / \mathrm{g}, 65.0862 \mathrm{U} /(\mathrm{g} \bullet \mathrm{min})$, and $54.7725 \mathrm{U} /(\mathrm{g} \bullet \mathrm{min})$ at $300 \mathrm{mg} / \mathrm{L} \mathrm{Pb}$ concentration, respectively, and higher than that of the control by $3.20,22.34$, and $21.84 \%$, respectively. There were significant differences between CAT activity and the control at $300 \mathrm{mg} / \mathrm{L} \mathrm{Pb}$ concentration, while all of the antioxidant enzyme activities were significantly lower than that of the control under a concentration of $1200 \mathrm{mg} / \mathrm{L}$ treated.

\section{Photosynthetic parameters of Phoebe chekiangensis seedlings under different $\mathrm{Pb}$ concentrations}

In this experiment, $\mathrm{Pb}$ had significant influence on photosynthetic parameters. Most of the differences between treatments were also significant (Fig. 2). All of the photosynthetic parameters showed an upward firstly then downward trend as $\mathrm{Pb}$ concentration increased. The $\mathrm{Pn}, \mathrm{Gs}, \mathrm{Ci}$, and $\mathrm{Tr}$ reached their highest values in seedlings treated with $300 \mathrm{mg} / \mathrm{L}$ and were $41.38 \%, 39.01 \%, 3.94 \%$, and $26.30 \%$ higher than that in the control. As the $\mathrm{Pb}$ concentration increased continuously, the Pn, $\mathrm{Gs}, \mathrm{Ci}$, and $\mathrm{Tr}$ were generally reduced. Each treatment value was significantly lower than the control value, except the Pn under $600 \mathrm{mg} / \mathrm{L}$ treatment.

\section{Growth response of Phoebe chekiangensis seedlings under $\mathrm{Pb}$ stress}

Plant sensitivity and response to heavy metal $\mathrm{Pb}$ depend upon the plant genetic and physiological characteristics (Singh et al., 1997). Some plant species which have higher $\mathrm{Pb}$ accumulation have no bad influence on the growth under $\mathrm{Pb}$ stress, even can be promoted (Wierzbicka, 1995). Plant growth is the most observable reflection of the plant toxicity by heavy metals stress. In our present study, the growth of $P$. chekiangensis seedlings as indicated by SHI, GDI and biomass was promoted by the lower $\mathrm{Pb}$ concentration while inhibited by the higher $\mathrm{Pb}$ concentration, which was in agreement with the results by Lin and co-workers (Lin et al., 2017). 

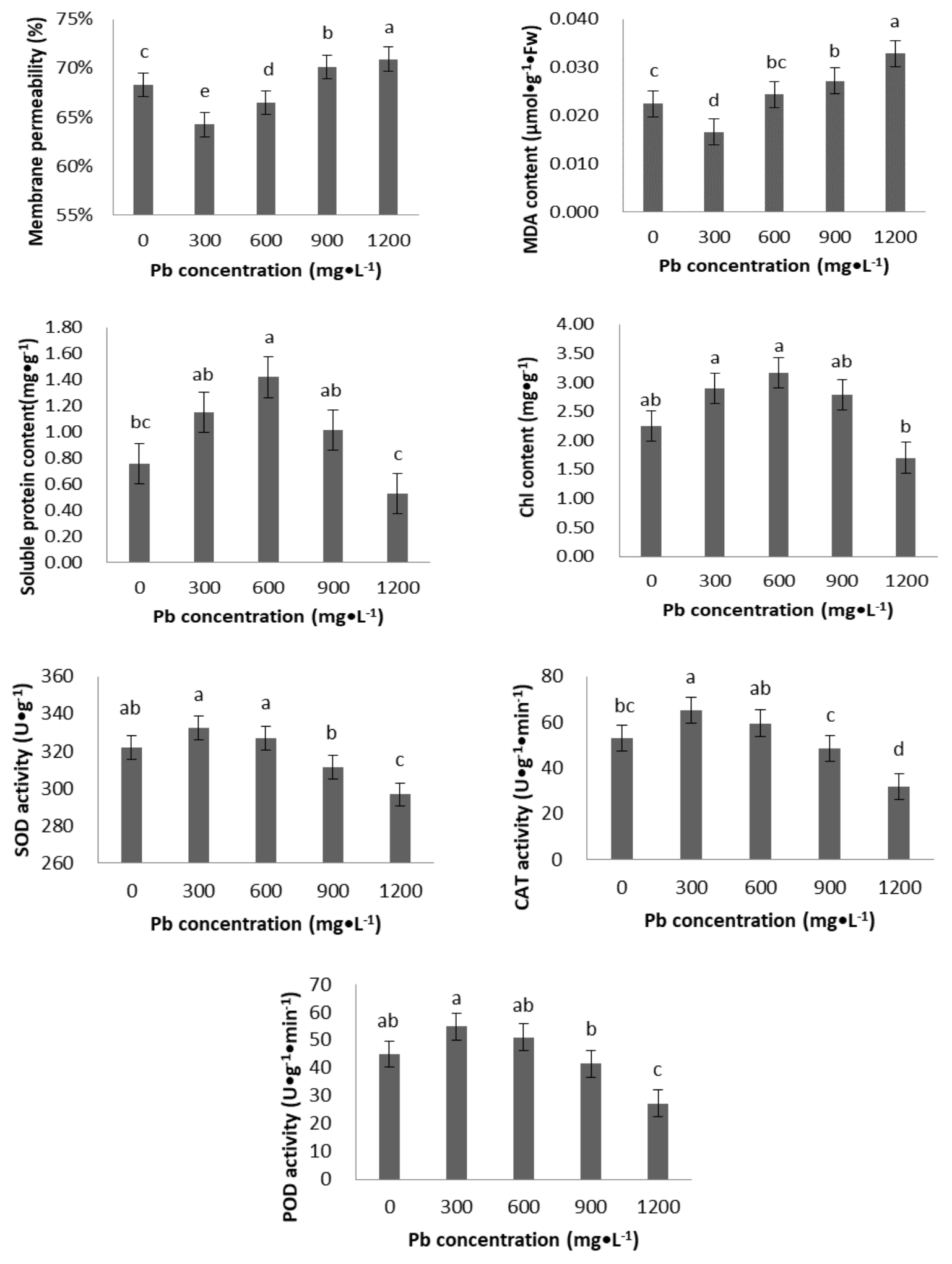

Fig. 1: Effects of physiological characteristics of Phoebe chekiangensis seedlings under different concentrations of $\mathrm{Pb}$ $\left(\mathrm{NO}_{3}\right)_{2}$ stress. The same alphabets between treatments did not differ significantly at $5 \%$ level by Duncan's multiple range test. 

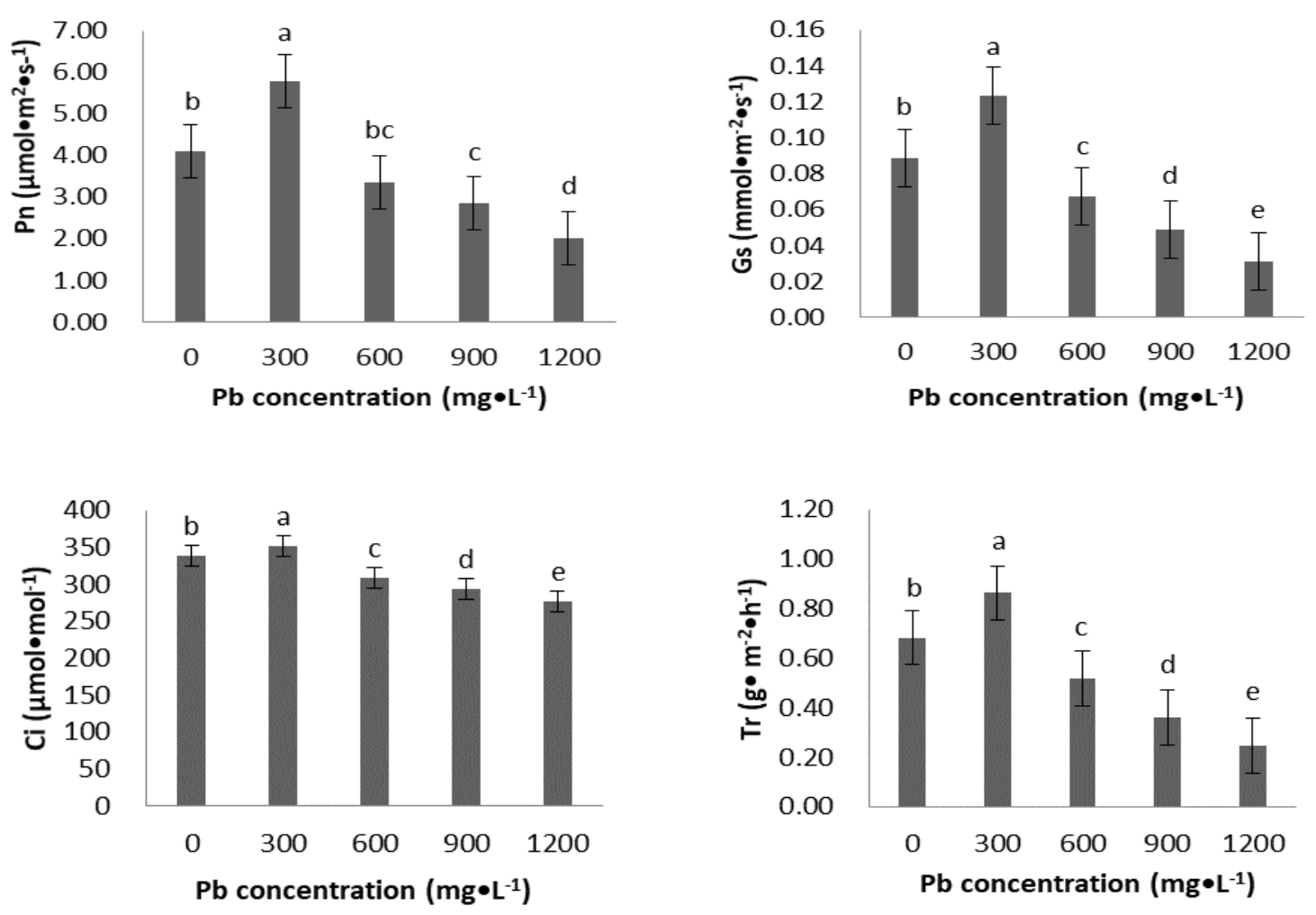

Fig. 2: Effects of photosynthesis parameters of Phoebe chekiangensis seedlings under different concentrations of $\mathrm{Pb}$ $\left(\mathrm{NO}_{3}\right)_{2}$ stress. The same alphabets between treatments did not differ significantly at $5 \%$ level by Duncan's multiple range test.

Table 1. Effects of the growth of Phoebe chekiangensis seedlings under different concentrations of $\mathrm{Pb}\left(\mathrm{NO}_{3}\right)_{2}$ stress.

\begin{tabular}{llllll}
\hline No. & $\begin{array}{l}\text { Pb concentration } \\
(\mathbf{m g} / \mathbf{L})\end{array}$ & $\begin{array}{l}\text { Seedling height } \\
\text { increment }(\mathbf{c m})\end{array}$ & $\begin{array}{l}\text { Ground diameter } \\
\text { increment }(\mathbf{c m})\end{array}$ & Biomass $(\mathbf{g})$ & $\begin{array}{l}\text { Root-shoot } \\
\text { ratio }\end{array}$ \\
\hline T0 & 0 & $1.68 \mathrm{c}$ & $0.060 \mathrm{c}$ & $4.57 \mathrm{~b}$ & $1.31 \mathrm{ab}$ \\
$\mathrm{T} 1$ & 300 & $2.24 \mathrm{a}$ & $0.073 \mathrm{a}$ & $4.97 \mathrm{a}$ & $1.29 \mathrm{~b}$ \\
$\mathrm{~T} 2$ & 600 & $1.91 \mathrm{~b}$ & $0.066 \mathrm{~b}$ & $4.71 \mathrm{ab}$ & $1.33 \mathrm{ab}$ \\
$\mathrm{T} 3$ & 900 & $1.34 \mathrm{~d}$ & $0.050 \mathrm{~d}$ & $3.72 \mathrm{c}$ & $1.35 \mathrm{ab}$ \\
T4 & 1200 & $1.21 \mathrm{e}$ & $0.044 \mathrm{e}$ & $3.34 \mathrm{~d}$ & $1.39 \mathrm{a}$ \\
\hline
\end{tabular}

The same alphabets between treatments did not differ significantly at $5 \%$ level by Duncan's multiple range test.

Table 2. Effects of the root growth of Phoebe chekiangensis seedlings under different concentrations of $\mathrm{Pb}\left(\mathrm{NO}_{3}\right)_{2}$ stress.

\begin{tabular}{lllllll}
\hline No. & $\begin{array}{l}\text { Pb concentration } \\
(\mathbf{m g} / \mathbf{L})\end{array}$ & $\begin{array}{l}\text { Total root } \\
\text { tips }\end{array}$ & $\begin{array}{l}\text { Root surface } \\
\text { area }\left(\mathbf{c m}^{2}\right)\end{array}$ & $\begin{array}{l}\text { Root volume } \\
\left(\mathbf{c m}^{3}\right)\end{array}$ & $\begin{array}{l}\text { Total root } \\
\text { length }(\mathbf{c m})\end{array}$ & $\begin{array}{l}\text { Root } \\
\text { activity }\end{array}$ \\
\hline T0 & 0 & $808.67 \mathrm{~b}$ & $18.19 \mathrm{ab}$ & $1.63 \mathrm{ab}$ & $253.14 \mathrm{~b}$ & $327.79 \mathrm{c}$ \\
$\mathrm{T} 1$ & 300 & $1354.67 \mathrm{a}$ & $20.64 \mathrm{a}$ & $2.31 \mathrm{a}$ & $302.78 \mathrm{a}$ & $377.64 \mathrm{a}$ \\
$\mathrm{T} 2$ & 600 & $725.33 \mathrm{~b}$ & $17.32 \mathrm{ab}$ & $1.35 \mathrm{ab}$ & $227.84 \mathrm{bc}$ & $344.64 \mathrm{~b}$ \\
$\mathrm{~T} 3$ & 900 & $618.33 \mathrm{~b}$ & $16.33 \mathrm{~b}$ & $1.20 \mathrm{~b}$ & $213.42 \mathrm{c}$ & $301.16 \mathrm{~d}$ \\
$\mathrm{~T} 4$ & 1200 & $490.67 \mathrm{~b}$ & $15.73 \mathrm{~b}$ & $0.96 \mathrm{~b}$ & $198.71 \mathrm{c}$ & $139.76 \mathrm{e}$ \\
\hline
\end{tabular}

The same alphabets between treatments did not differ significantly at 5\% level by Duncan's multiple range test. 
On the contrary, the root-shoot ratio had a downward firstly then upward trend. When under the $\mathrm{Pb}$ stress, plants distribute the limited nutrition to different functional organs to help adaptation or against the stress. In our study, in order to resist the $\mathrm{Pb}$ stress, $P$. chekiangensis seedlings transferred the nutrition to the roots to facilitate the root growth for more nutrients. As a result, the root biomass rise up and the root-shoot ratio gradually increased.

\section{Root growth response of Phoebe chekiangensis seedlings under $\mathrm{Pb}$ stress}

Roots are the most important organs for absorption of water and nutrients in plants. Heavy metals inhibit the root cell mitotic, affect root system development, and influence the roots to absorb water and nutrients. In our experiment, the root growth indicators were shown an increase firstly then decrease trend. These results agreed with the reports of Machilus pauhoi Kanehira (Zheng et al., 2015). The roots are the earliest tissues directly in contact with soil surrounding the $\mathrm{Pb}$ and also the location where the heavy metals have been taken up into the plants. Therefore, plant root plays an important role in tolerance mechanism.

In the previous research, there are two tolerance mechanisms related with plant roots. One is plant root cell wall which can bind the metals with proteins present in the epidermal cells of cell wall and ultimately reduce translocation and accumulation of heavy metals in upper parts (Shameem et al., 2016). The other is root exudates which result in chelation of heavy metal ions to detoxify (Ma et al., 2001). In Arabidopsis thaliana seedlings, root growth was inhibited while cytoplasm and major organelles were protected from $\mathrm{Pb}$ toxicity, and the heavy metal $\mathrm{Pb}$ was accumulated in the root cell wall (Ing et al., 2011). However, in our study, the root growth has been promoted under the lower $\mathrm{Pb}$ concentration. How an action of $\mathrm{Pb}$ and root cell wall might impact on root growth of $P$. chekiangensis is not clear. Therefore, the further research of $\mathrm{Pb}$ tolerance mechanism in $P$. chekiangensis should focus on the root cell wall and root secretions.

\section{Physiological response of Phoebe chekiangensis seedlings under $\mathbf{P b}$ stress}

Cell membrane can control and adjust the transport and exchange of intracellular substances by its selectively permeability. The permeability value reflects the amount of soluble substance leakage within the cell membrane, so is the evaluation index of the reaction of plants to environmental damage. Results from our study showed that the membrane permeability decreased firstly then increased. It revealed that the seedlings detoxified the $\mathrm{Pb}$ stress by decreasing the membrane permeability at lower $\mathrm{Pb}$ concentration. With the $\mathrm{Pb}$ concentration continuing increased, the structure and function of plant cell membrane was harmed by the $\mathrm{Pb}$ stress, membrane stability decreased, passive leakage of ion cells and macromolecules. MDA, which is the final decomposition product of the lipid peroxidation due to oxidative stress, is also an indicator of membrane damage degree. In our study, MDA content showed a similar trend with membrane permeability.

In contrast to membrane permeability and MDA content, soluble protein and chlorophyll contents in leaf tissues increased firstly then reduced. Protein is the main component of cell and organelle, enzyme and membrane. Under the lower concentration of $\mathrm{Pb}$, plant growth increased with a accompanying of a substantial increase of the cell, membrane and enzyme in plant, resulted in an increase of soluble protein content.

The growth of $P$. chekiangensis seedlings was inhibited by the $\mathrm{Pb}$ stress at the higher concentration, so the content of soluble protein gradually reduced. Chlorophyll plays a very important role in the plant photosynthesis. At the higher concentration of $\mathrm{Pb}$, the $\mathrm{Pb}$ ion inhibited the generation of enzymes which take part in the synthesis of chlorophyll, induced excessive ROS and free radicals which affected the stability of chlorophyll structure, and competed with $\mathrm{Mg}$ ion to synthesis of chlorophyll. A lot of researches have reported the plant leaves chlorosis problem as a result of heavy metal stress (Shameem et al., 2016). 
Normally, plants evolved complex antioxidant defense system to repair the damage initiated by ROS. SOD can catalyze the dismutation of $\mathrm{O}^{2-}$ into $\mathrm{H}_{2} \mathrm{O}_{2}$ and $\mathrm{O}_{2}$. The $\mathrm{H}_{2} \mathrm{O}_{2}$ was then resolved by CAT and POD into $\mathrm{H}_{2} \mathrm{O}$ and $\mathrm{O}_{2}$. In present study, the enhancement of activities of antioxidant enzymes (SOD, CAT, POD) at the lower concentration of $\mathrm{Pb}$, was an stress response which could keep the steady state level of ROS. Elevated concentration of $\mathrm{Pb}$ continuously, excessive ROS disturbed the homeostasis of ROS and antioxidant enzymes in plants. The activities of SOD, CAT, and POD declined and the plants were damaged by the $\mathrm{Pb}$ stress.

\section{Photosynthetic response of Phoebe chekiangensis seedlings under $\mathrm{Pb}$ stress}

Stomatal and nonstomatal inhibitors are generally thought to affect the plant photosynthesis during environmental stress (Lin et al., 2017). Results from our study, the $\mathrm{Pn}, \mathrm{Gs}, \mathrm{Ci}$, and $\mathrm{Tr}$ showed an increasing then decreasing trend, indicated that P.chekiangensis seedlings enhanced photosynthesis and produced more nutrients for plant growth under lower $\mathrm{Pb}$ concentration while were toxic with $\mathrm{Pb}$ concentration continuously increased which were in consistent with the results of other indicators in our study. At higher $\mathrm{Pb}$ concentration condition, $\mathrm{Pb}$ stress impeded the synthesis of chlorophyll, degraded chlorophyll, and altered the enzyme activities which participated in the photosynthesis and chlorophyll synthesis in cells. As a consequence, the photosynthesis of seedlings reduced, and then plant grew slowly.

In conclusions, the effects of $\mathrm{Pb}$ on $P$. chekiangensis seedlings were reflected at the growth, physiological, enzyme, and photosynthetic levels. Under lower concentration of $\mathrm{Pb}$, all growth increased, membrane permeability and MDA content decreased, soluble protein and chlorophyll contents raised, antioxidant enzyme activities enhanced, and photosynthesis was promoted. The growth and physiological characteristics of $P$. chekiangensis seedlings were inhibited when exposed to higher concentration of $\mathrm{Pb}$. Based on these results, we suspected that $P$. chekiangensis was a $\mathrm{Pb}$ tolerant plant which might have an active and efficient mechanism of protecting plant against $\mathrm{Pb}$ stress. $P$. chekiangensis seedlings are promising for phytoremediation of $\mathrm{Pb}$-polluted soils.

\section{Conflict of interest statement}

Authors declare that they have no conflict of interest.

\section{Acknowledgments}

This work was supported by Hubei science and technology support program (2013BBB24), Phoebe special investigation of the second national survey on the key conservation of wild plant resources in Hubei, China, and the Yangtze Initial Fund (801190010133).

\section{References}

Arya, S.K., Basu, A., Mukherjee, A., 2013. Lead induced genotoxicity and cytotoxicity in root cells of Allium cepa and Vicia faba. Nucleus. 56, 183-189.

Dalton, D.A., 1995. Antioxidant defenses of plants and fungi. In: Oxidative Stress and Antioxidant Defenses in Biology (Ed.: Sami, A.). Chapman \& Hall, New York. pp.298-354.

Foyer, C. H., Descourvieres, P., Kunert, K. J., 1994. Protection against oxygen radicals: An important defense mechanism studied in transgenic plants. Plant Cell Environ. 17, 507523.

Ghnaya, T., Zaier, H., Baioui, R., Sghaier, S., Lucchini, G., Sacchi, A. G., Lutts, S., Abdelly, C., 2013. Implication of organic acids in the long-distance transport and the accumulation of lead in Sesuvium portulacastrum and Brassica juncea. Chemosphere. 90(4), 1449-1454.

Huang, B., 2017. The technique of bud propagation in tissue culture of Phoebe chekiangensis. Fujian Linye. pp.45-48.

Ing, C. P., David, W. M. L., Taylor, H. H., David, J. B., 2011. Correlation of growth inhibition with accumulation of $\mathrm{Pb}$ in cell wall and changes in 
response to oxidative stress in Arabidopsis thaliana seedlings. Plant Growth Regul. 64, 1725.

Kasim, W. A., Abokassem, E. M., Ragab, G. A., Sewelam, N. A., 2014. Alleviation of lead stress toxicity in Vigna unguiculata by salicylic acid. Egypt. J. Exp. Biol. (Botany) 10, 37-49.

Lamhamdi, M., Galiou, O. E., Bakrim, A., NóvoaMuñoz, J. C., Arias-Estévez, M., Aarab, A., Lafont, R., 2013. Effect of lead stress on mineral content and growth of wheat (Triticum aestivum) and spinach (Spinacia oleracea) seedlings. Saudi J. Biol. Sci. 20, 29-36.

Li, D. L., Xiang, Q. B., 2004. Effects of light condition on the growth and photosynthetic characters of Phoebe chekiangensis seedlings. J. Nanjing For. Univ. (Natural Sci. Edn.) 28(5), 27-31.

Li, D. L., Xiang, Q. B., 2006. Effects of soil moisture status on the Phoebe chekiangensis seedings. J. Nanjing For. Univ. (Natural Sci. Edn.) 30(5), 112-114.

Li, Y. G., Liu, X. H., Ma, J. W., Li, F. F., Shi, C. J., Yang, S. Z., 2015. Effects of cultivation measures on growth and root morphology of container seedlings of Phoebe chekiangensis. J. Northeast For. Univ. 43(1), 41-44.

Lin, J. H., Li, J., Li, G., Dai, B. X., Shi, X. L., Shen, J., Hu, Y. Y., Wu, J. S., Song, L. L., 2017. Effect of lead stress on growth and physiological properties in Torreya grandis seedlings. J. Zhejiang For. Sci. Technol. 37(1), 33-40.

Ma, L. Q., Komarc, K. M., Zhang, T. U. W., Cai, Y., 2001. A fern that hyperaccumulates arsenic. Nature. 409-579.

Malecka, A., Jarmuszkiewicz, W., Tomaszewska, B., 2001. Antioxidative defense to lead stress in subcellular compartments of pea root cells. Acta Biochim. Polon. 48, 687-698.

Michalak, A., 2006. Phenolic compounds and their antioxidant activity in plants growing under heavy metal stress. Pol. J. Environ. Stud. 15, 523-530.

Mukesh, K., Raikwar, Kumar, P., Singh, M., Singh, A., 2008. Toxic effect of heavy metals in livestock health. Vet. World. 1(1), 28-30.
Qiu, Y. B., Qiao, W. Y., Liu, J., Jiang, J. M., Jiang, A. P., 2016. Influence of container size, substrate and fertilizer on big container-growing seedling quality of Phoebe chekiangensis. J. Northeast For. Univ. 44(9), 20-23.

Seregin, I. V., Kozhevnikova, A. D., 2008. Roles of root and shoot tissues in transport and accumulation of cadmium, lead, nickel, and strontium. Russ. J. Plant Physiol. 55, 1-22.

Shameem, R., Asif, A., Masooma, N. C., 2016. Plants tolerance mechanism and physiological effects under heavy metals stress. Int. J. Agric. Environ. Res. 2(2), 125-132.

Sharma, P., Dubey, R. S., 2005. Lead toxicity in plants. Braz. J. Plant Physiol. 17, 35-52.

Sharmaa, R. K., Agrawala, M., Marshall, F., 2007. Heavy metal contamination of soil and vegetables in suburban areas of Varanasi, India Ecotoxicol. Environ. Saf. 66, 258-266.

Singh, R. P., Tripathi, R. D., Sinha, S. K., Maheshwari, R., Srivastava, H.S., 1997. Response of higher plants to lead contaminated environment. Chemosphere. 34, 2467-2493.

Verma, S., Dubey, R. S., 2003. Lead toxicity induces lipid peroxidation and alters the activities of antioxidant enzymes in growing rice plants. Plant Sci. 164, 645-655.

Wang, Y., Wang, X. H., Wu, X. L., Zhang, L. Z., Wu, L. R., Xu, Y. M., Zhou, Z. C., 2013a. Effects of slow-release fertilizer loading on growth and construction of nutrients reserves of Phoebe chekiangensis and Phoebe bournei container seedlings. Sci. Silv. Sin. 49(12), 57-63.

Wang, Y., Wang, X. H., Zhang, L. Z., Wu, L. R., Zhou, Z. C., Xu, Y, M., 2013b. Effects of different cultivation substrates on growth and root system development of container seedlings of Phoebe chekiangensis and P. bournei. J. Plant Resour. Environ. 22(3), 81-87.

Wierzbicka, M., 1995. How lead loses its toxicity to plants. Acta Soc. Bot. Pol. 64(1), 81-90.

Wińska-Krysiak, M., Koropacka, K., Gawroński, S., 2015. Determination of the tolerance of sunflower to lead-induced stress. J. Elementol. 20, 491-502.

Xiang, Q. B., 1974. A new species in Phoebe genus-Phoebe chekiangensis. Acta Phytotaxon. 
Sin. 12(3), 295-297.

Yadav, S. K., 2010. Heavy metals toxicity in plants: An overview on the role of glutathione and phytochelatins in heavy metal stress tolerance of plants. South Afr. J. Bot. 76, 167-179.

Yan, Z. Z., Tam, N. F., 2011. Temporal changes of polyphenols and enzyme activities in seedlings of Kandelia obovata under lead and manganese stresses. Marine Pollut. Bull. 63, 438-444.

Zang, M., Qiu, X. L., Yao, L. F., 2015. Analysis of structure features and species diversity of Phoebe chekiangensis community in Sanqingshan mountain of Jiangxi province. J.
Anhui Normal Univ. (Natural Sci.) 38(3), 267271.

Zheng, S. X., Lin, J., Teng, W. C., Pan, H. B., Wen, M. J., Hou, W. J., Hu, H. Z., Wang, L. H., 2015. Growth and physiological mechanism of Machilus pauhoi seedlings in response to lead nitrate stress. J. For. Eng. 29(3), 25-30.

Zhou, J., Jiang, Z. P., Ma, J., Yang, L. F., Wei, Y., 2017. The effect of lead stress on photosynthetic function and chloroplast ultrastructure of Robinia pseudoacacia seedlings. Environ. Sci. Poll. Res. 24, 1071810726.

\section{How to cite this article:}

Yang, Y. J., Li, W, J., Fei, Y.J., 2018. Growth and physiological mechanism of Phoebe chekiangensis seedlings in response to lead stress. Int. J. Curr. Res. Biosci. Plant Biol. 5(4), 36-46. doi: https://doi.org/10.20546/ijcrbp.2018.504.006 